\title{
HIGH PRESSURE PROCESSING OF FOODS FOR MICROBIOLOGICAL SAFETY AND QUALITY*
}

\section{(A SHORT REVIEW)}

\author{
M. LINTON $^{1}$, MARGARET F. PATTERSON $^{1,2}$ \\ ${ }^{1}$ Department of Agriculture for Northern Ireland and ${ }^{2}$ Department of Food Science, Food Science \\ Division, The Queen's University of Belfast, Newforge Lane, Belfast BT9 5PX, Northern Ireland, UK
}

(Received: 1 September 1999; accepted: 15 September 1999)

Keywords: high pressure processing, microbiological safety of food, quality of foods

\begin{abstract}
Consumers are demanding foods that are "natural", of good nutritional and sensory quality, free from chemical preservatives, microbiologically safe and with extended shelf-life. High pressure processing can, potentially, meet these criteria. Recent advances in equipment design now allow foods to be processed up to 900 MegaPascals (130,000 psi). However, further work is required to more fully understand the factors that can affect the response of microorganisms, including pathogens, to pressure so that treatments can be optimised and microbiological safety can be assured. This paper describes how the pressure resistance of microorganisms can vary depending on factors such as species, strain, stage of growth and food composition. Strategies for overcoming the problem of pressure resistance will be discussed, for example the use of pressure cycling and the combination of pressure with mild heat. The current commercial uses of high pressure to preserve foods will be reported and potential applications will also be discussed.
\end{abstract}

*A paper presented at the 13th International Congress of the Hungarian Society for Microbiology, August 28 - September 1, 1999, Budapest, Hungary 


\section{Introduction}

High pressure processing of foods is not a new concept. As far back as 1899 Hite [1] was investigating the use of high pressure for the preservation of milk. Recent advances in high pressure technology and the search for alternatives to the traditional heat processing of foods has led to a renewed interest in high pressure for extending the shelf-life and ensuring the microbiological safety of foods.

At present the products which are produced by high pressure processing are mainly high acid fruit products such as juices, jams, jellies, sauces and purees [2]. In Japan, for example, semi-continuous high pressure systems with a capacity of up to $6,000 \mathrm{l} / \mathrm{h}$ are used for the bulk treatment of citrus juices. Yeasts and moulds, which are the main cause of spoilage in these products, can be inactivated using relatively low pressures and shelf-life can be extended without adversely affecting colour and flavour and with only a slight decrease in vitamin $C$ content [3]. Other pressure processed foods commercially available include fish and shellfish, ham, rice products and guacamole [4, 5]. As the understanding of the effects of high pressure on foods increases and the conditions required for microbial inactivation are determined, the range and types of food processed by high pressure should increase.

\section{Units of pressure}

The SI unit of pressure is the Pascal. 1 Pascal $(\mathrm{Pa})=1$ Newton $/ \mathrm{metre}^{2}$

$100 \mathrm{MPa} \sim 1000$ atmospheres $\sim 1 \mathrm{kbar} \sim 15,000$ psi. Typically the pressures used in the treatment of foods are 100-1000 MPa.

\section{Principles of action}

There are two general scientific principles of direct relevance to the use of high pressures in food processing: (a) high pressure stimulates reactions that result in a volume decrease but retards reactions that involve a volume increase (Le Chatelier principle) and (b) pressure is transmitted in a uniform and instantaneous manner throughout the whole biological sample, whether the sample is in direct contact with the pressure medium or hermetically sealed in a flexible package that transmits pressure (the isostatic rule) [6]. Thus, the breaking of ionic bonds is enhanced by high pressure as this leads to a volume decrease due to electrostriction of water in the proximity of the ions. Hydrogen bonds tend to be stabilised by high pressure since their 
formation involves a volume decrease. The effects of high pressure on hydrophobic interactions depend on the intensity of pressure applied. Hydrophobic interactions are disrupted at pressures below $100 \mathrm{MPa}$. However, above $100 \mathrm{MPa}$ (as in most food applications) hydrophobic interactions tend to be stabilised due to a volume decrease. Covalent bonds are generally unaffected by pressure [7]. Pressure can therefore disrupt the three dimensional structure of larger molecules or cell structures (proteins, including enzymes, lipids, cell membranes, etc.) but have no effect on small covalently bonded molecules such as vitamins, flavour components and some pigments. The disruption of the various structures leads to the inactivation of microorganisms and enzymes and can induce textural changes in foods.

\section{Factors affecting inactivation of bacteria by high pressure}

High pressure inactivation of microorganisms is not clearly understood but normally involves a perturbation of the cell membrane. This has been shown in pressure treated cells by an increase in extracellular ATP [5] and by increased uptake of ethidium bromide and propidium iodide [8]. Further evidence of the importance of the membrane in pressure inactivation can be seen in the dependence of pressure resistance on the fluidity of the cell membrane. For example, Lactobacillus plantarum cells which were grown at sub-optimal temperature showed an increase in unsaturated fatty acid content and were more resistant to pressure [9].

Other mechanisms of action which may be responsible for microbial inactivation include the denaturation of key enzymes and the disruption of ribosomes. DNA is largely unaffected by high pressure but enzymes involved in replication and transcription may be inactivated [10].

A number of factors determine the resistance of a microorganism to pressure. Simple first order reactions (straight line relationships) have been reported for the inactivation of some vegetative bacteria by pressure [11]. However, other studies have shown that deviations from the first order might occur. In many cases the inactivation curves show exponential decay although the shape of the curves may change with treatment temperature. For example, first order kinetics were reported when Escherichia coli was treated at $250 \mathrm{MPa}$ at 40 or $50{ }^{\circ} \mathrm{C}$ over a period of $20 \mathrm{~min}$. However at temperatures below $30{ }^{\circ} \mathrm{C}$ the curve shape changed to that of exponential decay (second order kinetics) [12]. It was suggested that the "tail" indicated that a small fraction of the population appeared to be less sensitive when the temperature was below $30{ }^{\circ} \mathrm{C}$. These observations may be explained by an altered membrane composition of the organisms as a consequence of a liquid-gel transformation in the 
membrane near $30{ }^{\circ} \mathrm{C}$. Eze [13] reported such phase transitions in E. coli membranes. Similar exponential decay curves have been found when Yersinia enterocolitica, E. coli 0157:H7, Listeria monoctyogenes, Salmonella typhimurium and S. enteritidis are pressurised at $20{ }^{\circ} \mathrm{C}$ in phosphate buffered saline (PBS) at $\mathrm{pH} 7.0$ [14]. Metrick, Hoover and Farkas [15] also reported tailing effects for $S$. typhimurium and $S$. senftenberg pressurised from $238 \mathrm{MPa}$ to $340 \mathrm{MPa}$ at $23{ }^{\circ} \mathrm{C}$. In these studies, when the resistant tail population was isolated, grown and again exposed to pressure, there was no significant difference in the pressure resistance between it and the original culture. It has been suggested that the tailing phenomenon may be due to heterogeneity in the population, such as age, clumping, genetic variation or experimental conditions [16].

Gram-positive bacteria are generally more pressure resistant than Gramnegatives, while spores are most resistant and can survive pressures greater than 1000 MPa. However, there are some exceptions. Patterson et al. [14] found that E. coli O157:H7 could be relatively resistant to high pressure. Resistance varies between species and between different strains of the same species. For example Benito et al. [8] showed that strains of $E$. coli $\mathrm{O} 157: \mathrm{H} 7$ exhibited differences in resistance to high pressure and Patterson et al. [14] found a significant difference in pressure resistance between strains of both E. coli $\mathrm{O} 157: \mathrm{H} 7$ and L. monocytogenes. The reason for this variation between strains is not known but for some bacteria there is a correlation between pressure resistance and thermotolerance. Growth phase also has an effect on the pressure resistance, with bacteria in the log phase being more sensitive to high pressure than those in the stationary, dormant or death phase [10]. The composition of the pressurising medium also determines pressure resistance. Proteins, carbohydrates and lipids all confer resistance as does a reduced $\mathrm{A}_{\mathrm{w}}$. It is therefore important that process conditions are evaluated in real foods and not extrapolated from data obtained in other substrates.

The conditions during pressure treatment can have a significant effect on resistance. The temperature during pressurisation can have a marked effect on the inactivation of cells. In one study the destruction of microorganisms in $2 \mathrm{mM}$ sodium phosphate buffer, pH 7.0 was investigated [17]. Pressures ranging from 100 to 400 $\mathrm{MPa}$ were applied for $20 \mathrm{~min}$. at either $-20{ }^{\circ} \mathrm{C}$ or $+20{ }^{\circ} \mathrm{C}$. In most cases the microbial inactivation of vegetative organisms, including S. bareilly, V. parahaemolyticus and St. aureus, was greater at $-20{ }^{\circ} \mathrm{C}$ than at $+20{ }^{\circ} \mathrm{C}$. Similar trends were observed in another investigation where minced beef was inoculated with Citrobacter freundii (used as an indicator organism for Salmonella spp.) and subjected to high pressure processing for $20 \mathrm{~min}$ at a variety of temperatures [18]. A reduction of at least $10^{5}$ was obtained with $280 \mathrm{MPa}$ at $20{ }^{\circ} \mathrm{C}$, or $230 \mathrm{MPa}$ at $4{ }^{\circ} \mathrm{C}$ or $150 \mathrm{MPa}$ at $50{ }^{\circ} \mathrm{C}$. 
The combination of pressure with relatively mild heat may be a useful strategy for dealing with pressure resistant vegetative pathogens [19] and spores [20]. Simple models have been developed which predict the pressure and temperature conditions required to achieve a given level of inactivation in named foods. These conditions can then be used to determine the optimum treatment, in terms of sensory quality, suitable for each product [19].

The $\mathrm{pH}$ of the substrate also has an important effect on the pressure resistance and most microorganisms are more susceptible to high pressure when the $\mathrm{pH}$ of the suspending medium is sub-optimal. For example, it has been shown that the pressure resistance of E. coli $\mathrm{O} 157: \mathrm{H} 7$ in orange juice is dependent on the $\mathrm{pH}$ of the juice, the degree of inactivation increasing as $\mathrm{pH}$ decreases [21]. Survival of E. coli O157:H7 in orange juice during storage is also dependent on $\mathrm{pH}$. When E. coli $\mathrm{O} 157: \mathrm{H} 7$ was stored in orange juice at $3{ }^{\circ} \mathrm{C}$, following a mild pressure treatment (400 $\mathrm{MPa}$ for $1 \mathrm{~min}$ at 10 ${ }^{\circ} \mathrm{C}$ ) the survival times at low $\mathrm{pH}$ decreased relative to an untreated control (Table I).

Table I

Time taken during storage at $3{ }^{\circ} \mathrm{C}$ for the numbers of E. coli $\mathrm{O} 157: \mathrm{H} 7$ (NCTC 12079)

in orange juice to reduce by $5 \log$ cycles

\begin{tabular}{lcc}
\hline $\mathrm{pH}$ & \multicolumn{2}{c}{ Storage time (days) to achieve a $5 \log$ inactivation } \\
\cline { 2 - 3 } & Control & $400 \mathrm{MPa} / 1 \mathrm{~min} / 10^{\circ} \mathrm{C}$ \\
\hline 3.4 & 13 & 3 \\
3.6 & 16 & 6 \\
3.9 & $>25$ & 8 \\
\hline
\end{tabular}

These results indicate that the damage caused to E. coli O157:H7 during sublethal pressure treatment, made it more susceptible to the combination of low $\mathrm{pH}$ and low temperature encountered during refrigerated storage in orange juice. This effect should also be taken into consideration when enumerating bacteria after pressure treatment as selective media may not allow growth of pressure-injured cells which may subsequently multiply under suitable conditions.

Sublethal pressure treatment also reduces the thermotolerance of $E$. coli O157:H7. When E. coli $\mathrm{O} 157: \mathrm{H} 7$ was inoculated into skimmed milk and pressure 
treated at $200 \mathrm{MPa}$ for $30 \mathrm{~min}$ at $10{ }^{\circ} \mathrm{C}$ the $\mathrm{D}_{10}$ values obtained were significantly lower than those obtained in untreated controls (Table II).

This sensitisation to heat should be considered when conditions are being determined for combination treatments, such as high pressure treatment followed by heating.

Table II

D values (min) obtained when $E$. coli O157:H7 (NCTC 12079)

was suspended in skimmed milk

and pressure treated prior to heat treatment at 55,58 and $60{ }^{\circ} \mathrm{C}$

\begin{tabular}{lcc}
\hline Temperature $\left({ }^{\circ} \mathrm{C}\right)$ & \multicolumn{2}{c}{ D values $(\min )$} \\
\cline { 2 - 3 } & Control & $200 \mathrm{MPa} / 30 \mathrm{~min} / 10^{\circ} \mathrm{C}$ \\
\hline 55 & 16.38 & 10.50 \\
58 & 8.10 & 4.88 \\
60 & 2.44 & 1.51 \\
\hline
\end{tabular}

Future development of high pressure processed foods

Although high pressure offers opportunities for food processing there are a number of restrictions, which should be considered. The resistance of bacterial spores to high pressure may mean that high pressure will have to be used in tandem with heat or other processes to give the required level of inactivation in susceptible foods. Pressure combined with heat, and pressure followed by heat (or vice versa) have been suggested for the inactivation of spores. Pressure cycling, using alternating high and low pressure treatments has also been proposed as a method for increasing spore inactivation [20]. Spore germination can be induced using relatively low pressures and the germinated spores may then be inactivated by moderately high pressure [13].

Pressure-treated fruit juices also present a problem in that the high pressure treatments used do not inactivate polyphenol oxidase and consequently these products require chilling during storage to prevent enzymatic browning.

The range of commercially available pressure-processed products is small at present but there are opportunities for further development and the production of a 
wide range of pressure-treated products. High pressure affects the functionality of large protein and carbohydrate molecules, an attribute that may allow the optimisation of food manufacturing processes and the production of novel foods. For example, high pressure can be used to improve the functional properties of food and food ingredients such as the texture and emulsifying, whipping and dough forming properties [9]. Applications of high pressure include the production of high strength acid set gels, the restructuring of meat and fish, tenderization of meat, reduced ripening time for cheeses, tempering of chocolate and pressure shift freezing and thawing.

\section{References}

1. Hite,B.H.: The effect of pressure in the preservation of milk. Bull. 58;15 West Virginia Univ. Agr. Expt. Sta., Morgantown. 1899.

2. Cheftel,J.C.: Food Sci Tech Int 1, 75 (1995).

3. Kimura,K., Ida,M., Yosida,Y., Ohki,K., Fukumoto,T., Sakui,N.: Biosci. Biotech and Biochem 58, 1386 (1994).

4. Mussa,D.M., Ramaswamy,H.S., Smith,J.P.: High pressure destruction kinetics of Listeria monocytogenes on pork. J Food Prot 62, 40 (1999).

5. Smelt,J.P.P.M.: Recent advances in the microbiology of high pressure processing. Trends in Food Sci and Tech 9, 152 (1998).

6. Cheftel,J-C.: Effects of high hydrostatic pressure on food constituents: An overview. In Balny,C., Hayashi,R., Heremans,K., Masson,P. (eds): High Pressure and Biotechnology. Colloque INSERM/John Bibby and Co. Ltd. London, 1992. pp. 195-209.

7. Mertens,B.: Developments in high pressure processing. Z Lebensm Technol 44, 100 (1993).

8. Benito,A., Ventoura,G., Casadei,M., Robinson,T., Mackey,B.: Variation in resistance of natural isolates of Escherichia coli $\mathrm{O} 157$ to high hydrostatic pressure, mild heat and other stresses. Appl Environ Microbiol 65, 1564 (1999).

9. Smelt,J.P.P.M., Rijke,A.G.F., Hayhurst,A.: Possible mechanisms of high pressure inactivation of microorganisms. High Pressure Research 12, 199 (1994).

10. Hoover,D.G., Metrick,C., Papineau,A.M., Farkas,D.F., Knorr,D.: Food Tech March 99 (1989).

11. Butz,P., Ludwig,H.: Pressure inactivation of microorgansims at moderate temperatures. Physica 139u.140B, 875 (1986).

12. Ludwig,H., Bieler,C., Hallbauer,K., Scigalla,W.: Inactivation of microorganisms by hydrostatic pressure. In Balny,C., Hayashi,R., Heremans,K., Masson,P. (eds): High Pressure and Biotechnology. Colloque INSERM/John Bibby and Co. Ltd. London, 1992. pp. 25-32.

13. Eze,M.O.: Consequences of the lipid bilayer to membrane-associated reactions. J Chem Education 67, 17 (1990).

14. Patterson,M.F., Quinn,M., Simpson,R., Gilmour,A.: J. Food Prot 58, 524 (1995).

15. Metrick,C., Hoover,D.G., Farkas,D.F.: Effects of high hydrostatic pressure on heat resistant and heat sensitive strains of Salmonella. J Food Sci 54, 1547 (1989). 
16. Earnshaw,R.G.: Kinetics of high pressure inactivation of microorganisms. In Ledward,D.A., Johnston,D.E., Earnshaw,R.G., Hastings,A.P.M. (eds): High Pressure Processing of Foods. Nottingham University Press, 1995. pp. 37-46.

17. Takahashi,K., Ishii,H., Ishikawa,H.: Sterilisation of microorganisms by hydrostatic pressure at low temperatures. In Hayashi,R. (ed.): High Pressure Science of Food. Kyoto: San-Ei publishing Co. 1991. pp. 225-232.

18. Carlez,A., Rosec,J.P., Richard,N., Cheftel,J.C.: High pressure inactivation of Citrobacter freundii, Pseudomonas fluorescens and Listeria innocua in inoculated minced beef muscle. Lebensm-Wiss UTechnol 26, 357 (1993).

19. Patterson,M.F., Kilpatrick,D.J.: The combined effect of high hydrostatic pressure and mild heat on inactivation of pathogens in milk and poultry. J Food Prot 61, 432 (1998).

20. Mills,G., Earnshaw,R., Patterson,M.F.: Effects of high hydrostatic pressure on Clostridium sporogenes spores. Lett Appl Microbiol 26, 227 (1998).

21. Linton,M., McClements,J.M.J., Patterson,M.F.: Inactivation of E. coli O157:H7 in orange juice using a combination of high pressure and mild heat. J Food Prot 62, 277 (1999). 